\title{
PEMBAHARUAN DAKWAH PENDIDIKAN ISLAM DI SUMATERA BARAT
}

\author{
${ }^{1}$ Nurul Syalafiyah, ${ }^{2}$ Budi Harianto \\ ${ }^{1}$ IAI Pangeran Diponegoro Nganjuk, ${ }^{2}$ IAIN Tulungagung \\ ${ }^{1}$ nurulsyalafivah@gmail.com, ${ }^{2}$ budiharianto744@gmail.com
}

\begin{abstract}
ABSTRAK
Sumatera Barat merupakan wilayah penting dalam perkembangan dakwah pendidikan Islam di Indonesia, karena ia merupakan wilayah pertama yang mengalami proses modernisasi dakwah pendidikan Islam pada awal abad ke-20an. Adanya pembaharuan yang terjadi di Minangkabau sendiri memiliki banyak faktor, baik internal maupun eksternal. Artikel ini membahas bagaimana pembaruhan dakwah dalam pendidikan Islam di Sumatera Barat. Dengan menggunakan filsafat sejarah penulis mencoba mendeskripsikan pembaharuan dakwah pendidikan Islam di Sumatera Barat tersebut. Hasil yang ditemukan penulis menghasilkan kesimpulan bahwa Sumatera Barat memiliki banyak tokoh pembaharu dalam dunia dakwah pendidikan Islam. Tokoh-tokoh yang memberikan pengaruh besar dengan adanya lembaga atau sekolah sebagai sarana dakwah yang ia dirikan adalah Abdullah Ahmad yang telah mendirikan Adabiyah School, yang telah memadukan ilmu umum dan ilmu agama. Rahmah el-Yunusiah telah mendirikan Madrasah Diniyah Putri. Rahmah adalah tokoh pendidikan Islam wanita pertama yang menaruh perhatian akan pentingnya pendidikan bagi kaum wanita, hingga ia mendapat gelar Syaikhah dari Senat Guru Besar Universitas alAzhar. Surau sebagai sarana dakwah dalam bidang pendidikan Islam di Sumatera Barat yang mengalami pembaharuan sintem dengan berkelas, adalah Sumatera Thuwalib, namun walau sistemnya berubah, namun mereka tetap menggunakan buku-buku lama (turast).
\end{abstract}

Key Word: Pembaharuan, Dakwah, Pendidikan Islam, dan Sumatera Barat

\section{PENDAHULUAN}

Sejak Islam masuk ke Indonesia, dakwah Islam dalam bingkai pendidikan telah ikut mengalami pertumbuhan dan perkembangan, karena melalui pendidikan Islam itulah, transmisi, sosialisasi, dan dakwah ajaran Islam dapat dilaksanakan dan dicapai hasilnya seperti yang dapat kita lihat sekarang. Sumatera Barat memiliki kedudukan yang sangat penting dalam perkembangan pendidikan Islam di Indonesia. Sejalan dengan perannya sebagai akar gerakan pembaharuan di Indonesia pada awal abad ke-20, Sumatera Barat juga termasuk wilayah pertama 
yang mengalami proses modernisasi pendidikan Islam. ${ }^{1}$ Dengan adanya politik etis pemerintahan Belanda mendorong lembaga pendidikan tradisional surau untuk melakukan pembaharuan menjadi lembaga pendidikan Islam modern, dan proses ini lebih dipercepat dengan kepulangan sejumlah ulama pembaharu Minangkabau yang menuntut ilmu di Timur Tengah dan menjadikan pendidikan sebagai salah satu agenda pembaharuan Islam. Demikianlah surau berkembang menjadi madrasah, yang tidak hanya mengenalkan sistem baru tapi juga materi pembelajaran di luar ilmu-ilmu agama. ${ }^{2}$

Sistem pendidikan madrasah inilah yang kemudian berkembang di Sumatera Barat. Ia menjadi satu jenis pendidikan Islam yang tersebar luas hampir di seluruh wilayah Sumatera Barat, yang secara perlahan menggantikan peran tradisional surau. Sistem madrasah ini terus berkembang sesuai dengan idealis para pendirinya yang dilatar belakangi oleh pendidikan yang mereka tempuh, ide-ide pembaharuan yang mempengaruhi pemiikiran mereka, dan pengalaman kehidupan yang mereka lalui, baik dalam kehidupan di lingkungan masyarakat setempat maupun pengaruh penjajah terhadap kehidupan sosial mereka.

\section{A. Dakwah Pendidikan Islam di Minagkabau Sebelum Pembaharuan}

Pendidikan dan pengajaran pada masa kerajaan Islam tegak dan kuat sebagai sarana dakwah. Ini dapat terlihat dengan lahirnya ulama-ulama di Minangkabau, seperti Syeikh Burhanuddin Ulakan, Tuanku Imam Bonjol, dll. Namun setelah kerajaan Islam jatuh dan kaum Padri dikalahkan oleh penjajah Belanda, maka mulailah pendidikan dan pengajaran Islam mundur. Walau demikian pendidikan dan pengajaran di surau-surau tetap berjalan. ${ }^{3}$

Surau adalah lembaga pendidikan Islam yang ada Sebelum terbentuknya madrasah di Minangkabau. Selain menjadi tempat shalat, juga digunakan untuk pengajaran dan pengembangan Islam. Sebenarnya istilah surau sendiri sudah dikenal sebelum datangnya Islam ke Minangkabau. Surau dalam sistem adat Minangkabau adalah kepunyaan suku atau kaum sebagai pelengkap rumah gadang

${ }^{1}$ Abuddin Nata, Tokoh-Tokoh Pembaharuan Pendidikan Islam di Indonesia, (Jakarta: PT RajaGrafindo Persada, 2004), 1.

${ }^{2}$ Jajat Burhanuddin, dkk, Mencetak Muslim Modern, (Jakarta: Rajawali Press, 2006), 23.

${ }^{3}$ Mahmud Yunus, Sejarah Pendidikan Islam di Indonesia, (Jakarta, Hidakarya Agung, 1996), 33. 
yang berfungsi sebagai tempat bertemu, rapat, dan tempat tidur bagi anak laki-laki yang telah akil baligh. Kenyataan ini menyebabkan surau menjadi tempat amat penting bagi pendewasaan generasi Minangkabau. ${ }^{4}$

Syaikh Burhanuddin (1641-1691) selain seseorang yang telah menyebarkan tarekat syatariyah di Sumatera Barat, ${ }^{5}$ beliau pula Ulama yang pertama kali melakukan Islamisasi surau di Minangkabau. Pendidikan surau ini hidup semenjak Syaikh Baharuddin mendirikan suraunya di Ulakan, Pariaman tahun 1680. Sepeninggalannya estafet dilanjutkan oleh putra-putra dan muridmuridnya. $^{6}$

Berbeda dengan pendidikan umum, surau tidak berdasarkan sistem dan metode pendidikan. Untuk Mata pelajaran utamanya adalah al-Qur'an, Tafsir, Fiqh, Nahwu, Sharf, mengenai Rukun Iman dan Islam, ibadah dan akhlak. Buku acuan pun belum ada, semua tergantung pada guru atau tuanku. Sore dan malam hari adalah waktu belajarnya, dan jenjang Waktu yang ditempuh dalam belajar tidak dibatasi, bisa dua atau tiga tahun bahkan bisa sampai sebelas atau dua belas tahun. Pendidikan ini mereka dapatkan secara cuma-cuma, dan yang menerapkan iuran sekali pun hanya untuk membeli minyak lampu sebagai penerang waktu belajar. $^{7}$

Masing-masing tuanku memiliki kelebihannya masing-masing, maka orang mengaji pindah dari surau yang ke surau yang lain. Kebiasaan mengaji dengan berpindah surau dengan banyak tuanku merupakan kebanggaan tersendiri. Bagi yang merasa kajiannya sudah tinggi ia kan mencari surau atau tuanku yang akan menguji kajiannya. Setelah itu ia akan mulai mendirikan pengajian sendiri dan mungkin juga ia akan menjadi tuanku dan memiliki surau sendiri. ${ }^{8}$

\footnotetext{
${ }^{4}$ Samsul Nizar, Sejarah Pendidikan Islam; Menelusuri Jejak Sejarah Pendidikan Era Rasulullah Sampai Indonesia, ( Jakarta: Kencana, 2007), 280.

${ }_{5}$ M. Sholihin, Melacak Pemikiran Tasawuf di Nusantara, (Jakarta: PT RajaGrafindo Persada, 2005), 70.

${ }^{6}$ Musyrifah Sunanto, Sejarah Peradaban Islam Indonesia, (Jakarta: PT RajaGrafindo Persada, 2012), 109.

7 Burhanuddin Daya, Gerakan Pembahruan Pemikiran Islam kasus Sumatra Thawalib, (Yogyakarta: PT Tiara Wacana Yogya, 1995), 80.

${ }^{8}$ Ibid, 80.
} 
Kelanjutan pendidikan setelah belajar di surau bukanlah suatu keharusan bagi kebanyakan orang, hal tersebut tergantung individu masing-masing. Bagi yang ingin memperdalam kajinya, ia terus mengaji apa yang ia ingin dalami. Jurusan utama yang bisa dimasuki adalah jurusan hakikat, pengajiannya di surau guru tarekat dan tasawuf, sedangkan dan jurusan syariat dengan kajian fikih, hadis, atau tafsir. ${ }^{9}$

\section{B. Faktor Pembaharuan pendidikan Islam Sumatera Barat Sebagai Sarana Dakwah}

Ketika kita membahas faktor pembaharuan pendidikan Islam di Sumatera Barat sebagai sarana dakwah, secara tidak langsung kita juga akan membahas pembaharuan pemikiran Islam itu sendiri, diantara faktor penyebabnya adalah :

a. Faktor Eksternal

Pembukaan terusan Suez tahun 1869 memiliki faktor penting dalam hal ini karena ia memperlancar hubungan antara kota Mekah dengan Indonesia, sehingga orang Indonesia yang datang ke Mekkah ada yang bermukim untuk menuntut ilmu. Selain itu kewajiban menunaikan ibadah haji juga mendorong banyaknya orang Indonesia yang datang ke kota Mekkah. Mereka yang menunaikan ibadah haji sekalipun tidak hanya melaksanakan ibadah namun juga menuntut ilmu kepada syaikh. Sekembalinya mereka dari Mekkah mereka mengajarkan apa yang telah mereka peroleh. ${ }^{10}$

Selain itu, dua orang tokoh yang dipandang sangat penting menyalakan api pembaharuan pada abad ke-19 adalah Jamal al-Din al-Afgani dan Muhammad Abduh. yang mereka bawa adalah semangat ijtihadi dan menolak taqlid. Mereka juga memberi dukungan kepada umat Islam untuk mempelajari ilmu pengetahuan yang lebih luas. Semangat inilah yang dibawa para ulama yang belajar di Timur Tengah, khususnya Kairo, Mekah dan Madinah. ${ }^{11}$

\footnotetext{
${ }^{9}$ Ibid, 81 .

${ }^{10}$ Mundzirin Yusuf, dkk, Sejarah Peradaban islam di Indonesia, (Yogyakarta, Penerbit Pustaka, 2006), 149.

${ }^{11}$ Maksum, Madrasah; Sejarah dan Perkembangannya, (Jakarta: PT Logos Wacana Ilmu, 1999), 88 .
} 
Abad ke-19 Kairo dipandang sebagai sentral penerbitan baik buku dan jurnal berbahasa Arab maupun melayu. Penerbit yang terkenal saat itu adalah Mustafa al-Baby al-Halaby, ia memberikan sumbangan yang cukup signifikan dalam penyebaran gagasan pembaharuan ke wilayah Indonesia. Mahasiswa yang belajar disana banyak yang mengirimkan tulisan-tulisan kalangan pembaharu Timur Tengah. Dikatakan juga bahwa tokoh pembaharu di Indonesia pada awal abad 20 membaca secara rutin majalah al-Manar yang sekaligus merangsang mereka melakukan pembaharuan. Ditambah lagi dengan munculnya majalahmajalah berbahasa melayu, al-Imam di Singapura tahun 1906-1977, tidakkalah semangat di Indonesia juga ada al-Munir di Padang antara 1911-1916, dan jurnal berbahasa Arab al-Irsyad di Pekalongan. Dalam jurnal-jurnal tersebut ide-ide pembaharuan dikemukakan dalam masalah keislaman termasuk di dalamnya masalah pendidikan. ${ }^{12}$

b. Faktor Internal

Untuk faktor internal sendiri yang menyebabkan timbulnya pembaharuan adalah banyaknya praktek-praktek keagamaan dalam masyarakat yang sudah bercampur aduk dengan adat dan kebiasaan lokal. Hal ini dikarenakan pengamalan agama hanya dengan taqlid yang tidak berdasarkan ijtihad dari alQur'an dan Hadis. Peraktek bermadzhab dianggap sebagai sebab utama munculnya peraktek agama yang bersifat taqlidi. Apa yang diperkenalkan oleh para Imam madzhab itulah yang mereka pahami sebagai ajaran agama. Kitabkitab modern yang mencoba memahami secara langsung al-Qur'an dan Hadis diabaikan. Lebih dari itu, bidang studi non-keagamaan yang memang tidak tersedia dalam kitab-kitab klasik tidak diajarkan. Hal ini membuat para ulama pembaharu ingin merubah pola yang ada. ${ }^{13}$

Selain itu sekolah yang ditawarkan oleh kolonial Belanda pun bersifat diskriminatif. Walupun banyak kebijakan-kebijakan baru dalan ranah pendidikan namun tetap saja diskriminatif masih terlihat jelas. Hal ini menyebabkan rakyat Indonesia akan tetap bodoh karena tingkat pendidikan yang diperkenalkan bagi

\footnotetext{
${ }^{12}$ Ibid, 90.

${ }^{13}$ Abdul Sani, Lintasan Sejarah Pemikiran Perkembangan Modern Dalam Islam, (Jakarta: PT RajaGrafindo Persada, 1998), 193.
} 
mereka hanya sebatas pada sekolah rendah. Dari sudut ini, pendidikan Islam memiliki tanggung jawab untuk meningkatkan kecerdasan mereka. Dan disisi lain sudah saatnya bagi pendidikan Islam untuk menawarkan pola pendidikan yang lebih maju, baik dalam hal kelembagaan, struktur materi, maupun metodologi, sehingga dapat mengimbangi sekolah-sekolah ala Belanda. ${ }^{14}$

Karel A Steenbrink juga berpendapat bahwa gerakan pembaharuan Islam di Indonesia yang pasti di dalamnya Minagkabau pada awal abad ke-20 dilatarbelakangi oleh kesadaran dan semangat yang kompleks, antara lain : ${ }^{15}$

1. Keinginan untuk kembali kepada al-Qur'an dan Hadis

2. Semangat nasionalisme dan melawan penjajahan

3. Memperluas basis gerakan sosial, budaya, dan politik

4. Pembaharuan pendidikan Islam di Indonesia

Pendapat Karel di atas memang sangat sesuai dengan keadaan Indonesia saat itu berada dalam jajahan Belanda, dan khususnya Minangkabau yang dilanda oleh kebiasaan taqlid-nya.

\section{Pembaharuan Dakwah Pendidikan Islam Di Sumatera Barat}

Pendidikan Islam sebagai sarana dakwah menurut sistem lama, hanya terdiri dari dua tingkat saja; pengajian Qur'an dan pengajian kitab. Kemudian dengan banyaknya pelajar dan guru-guru yang pergi naik haji ke Mekkah dan sambil menuntut ilmu disana bertahun-tahun lamanya.Setelah mereka kembali ke Indonesia, mereka mengajarkan ilmu-ilmu agama dan bahasa Arab yang mereka pelajari. Dengan begitu mutu ilmu agama menjadi lebih baik. Perbedaan yang mencolok adalah pelajaran ilmu sharaf, Nahwu, Fiqh, dan Tafsir yang dahulu hanya menggunakan satu kitab menjadi menggunakan bermacam-macam kitab. Sehingga berkembanglah ilmu agama dan ilmu bahasa. ${ }^{16}$

Kitab yang dahulunya hanya dalam bentuk tulisan tangan menjadi menggunakan buku cetak yang awalnya dibawa oleh orang dari Mekkah dan dari Singapore. Kemudian oleh toko buku Syeikh Ahmad Khalidi di Bukit Tinggi

\footnotetext{
${ }^{14}$ Suwedi, Sejarah dan Pemikiran Pendidikan islam, 69.

${ }^{15}$ Samsul Nizar, Sejarah Pendidikan Islam; Menelusuri Jejak Pendidikan Era Rasulullah Sampai Indonesia, (Jakarta: Kencara, 2007), 291.

${ }^{16}$ Mahmud Yunus, Sejarah Pendidikan Islam di Indonesia, 55.
} 
dipesan sendiri ke Mesir. Toko buku yang lain juga mengikutinya, hingga banyak kitab-kitab agama yang datang dari Mesir, termasuk di dalamnya majalah almanar yang membawa aliran baru dalam Islam, yang diplopori oleh Syeikh Jamaluddin al-Afghani, Muhammad 'Abduh, Rasyid Ridho, dll. ${ }^{17}$

Jika kita membahas pembaharuan pendidikan Islam di Sumatera Barat, esensinya kita berbicara tentang pembaharuan pemikiran Islam disana. karena para tokoh yang memprakarsai pembaharuan pendidikan itu sendiri adalah tokohtokoh yang terpengaruh oleh ide-ide pembaharuan yang terjadi di negara tempat mereka menimba ilmu. Selain itu gerakan Pembaharuan yang dibawa oleh tokohtokoh tersebut memang tumbuh melalui lembaga pendidikan yaitu surau dan juga melalui tulisan-tulisan. Karena pembaharuan sistem pendidikan dipandang sebagai langkah strategis dalam membangun masyarakat.

\section{Tokoh Pembaharuan Dakwah Pendidikan Islam di Sumatera Barat}

Terjadinya pergolakan sosial dan intelektual di Sumatera Barat bermula pada Awal abad ke-20, dengan kembalinya tiga orang ulama Minangkabau yang menuntut ilmu di kota Mekah, yaitu Inyik Djambek, Inyik Rasul, Inyik Abdullah Ahmad, membawa semangat modernisasi Islam ajaran Muhammad Abduh, Jamaluddin al-Afghani dari Mesir. Walaupun sebelum abad ke-20 pembaharuan di Minangkabau sebenarnya sudah digerakkan oleh tiga haji yang datang dari mekah pada tahun 1803, yaitu haji Miskin, haji Sumanik dan haji Piambang. Yang dikenal dengan gerakan paderi, namun gerakan ini belum dalam bentuk pembaharuan pendidikan, hanya dalam proses pemurnian islam itu sendiri. ${ }^{18}$

a. Syaikh Ahmad Khatib

Syaikh Ahmad Khatib adalah seorang pelopor gerakan pembaruan di Minangkabau yang menyebarkan pikiran-pikirannya dari Mekkah pada awal abad ke-20. Ia merupakan keturunan dari seorang hakim gerakan Padri yang sangat anti penjajahan Belanda, dilahirkan di Bukit Tinggi pada tahun 1855. Ia meninggalkan kampung halamannya pergi ke Mekah pada tahun 1871 dibawa oleh ayahnya. Ia

\footnotetext{
${ }^{17}$ Ibid, 55.

${ }^{18}$ Yusran Asmuni, Dirasah Islamiyah III, Studi Pemikiran dan Gerakan Pembaharuan Dalam Islam, (Jakarta: PT RajaGrafindo Permai, 1998), 95.
} 
tak pernah kembali ke kampung halamannya, namun jasanya sebagai guru para calon ulama terkemuka abad ke-20 dan karya tulisnya, menjadikannya pelopor kelanjutan pembaharuan pemikiran Islam modern demi kemajuan Indonesia, terutama minangkabau. Murid-murid dari syaikh Ahmad Khatib kemudian menjadi penggerak pembaruan pemikiran Islam di Minangkabau, seperti Syekh Muhammad Djamil Djambek (1860 - 1947), Haji Abdul Karim Amarullah (1879-1945), dan Haji Abdullah Ahmad (1878 - 1933). ${ }^{19}$

b. Syaikh Abdullah Ahmad

Abdullah Ahmad, tokoh pembaharu pendidikan Islam dari Sumatera Barat, adalah pioner dan pelopor yang pertama kali memperkenalkan sistem madrasah. Ia lahir pada tahun 1878 di Padang panjang, sebagai anak dari haji Ahmad, yang dikenal sebagai seorang ulama di daerahnya. Pendidikannya dimulai dengan belajar agama Islam kepada ayahnya sendiri, setelah ia baligh, dimasukkan ke sekolah kelas dua (sekolah untuk kaum pribumi) di Padang Panjang. Pada usia 17 tahun ia berangkat ke Makkah untuk menunaikan ibadah haji dan juga menuntut ilmu (1895) pada syaikh Ahmad Khatib, dan ulama yang lainnya. Selama di sana ia juga mengikuti perkembangan gerakah Wahabiyah. ${ }^{20}$

Karena kerja keras dan ketekunannya dalam mempelajari ilmu agama di Makkah, ia diangkat sebagai asisten Syaikh Ahmad Khatib, dan pada tahun 1899 ia balik ke Minangkabau dan mulai mengajar di surau Jembatan Besi Padang Panjang, dan cara yang digunakan masih dengan sistem halaqah. Surau tersebut adalah cikal bakal dari Sumatra Thawalib. Ia memberantas bid'ah dan tarekat, ia juga tertarik dengan ide-ide pembaharuan melalui publikasi dengan jalan menjadi agen dari berbagai majalah. ${ }^{21}$

Pada tahun 1906 Abdullah Ahmad pindah ke Padang untuk menggantikan pamannya yang baru meninggal sebagai guru di surau. Di kota inilah ia mulai mendirikan sekolah agama pertama untuk Indonesia, dengan nama Adabiyah School. ${ }^{22}$ Untuk aktivitas yang berhubungan dengan intelektualnya, sejak muda ia

\footnotetext{
${ }^{19}$ Abuddin Nata, Tokoh-Tokoh Pembaharuan Pendidikan Islam di Indonesia, 12.

${ }^{20}$ Abuddin Nata, Pemikiran Para Tokoh Pendidikan Islam; Seri Kajian Filsafat Pendidikan Islam, (Jakarta: RajaGrafindo Persada, 2000), 157.

${ }^{21}$ Abuddin Nata, Tokoh-Tokoh Pembaharuan Pendidikan Islam di Indonesia, 13.

${ }^{22}$ Burhanuddin Daya, Gerakan Pembaharuan Pemikiran Islam, 82.
} 
selalu melakukan kontak intelektual dengan kaum terpelajar, baik siswa-siswa sekolah maupun guru-gurunya terdahulu, khususnya Syaikh Ahmad Khatib ,juga temannya yaitu Syaikh Jalaluddin, pemimpin majalah al-Iqbal dan majalah alImam di Singapura. Kontaknya dengan berbagai pemikiran modern ini cukup mempengaruhi pemikirannya. Selain kesibukannya dalam dunia dakwah dan pendidikan, ia juga aktif dalam bidang menulis mengenai keagamaan dan pendidikan. Karyanya yang terkenal adalah al-Munir, yaitu majalah yang mengandung misi pembaharuan Islam. ${ }^{23}$

c. Zainuddin Labay el-Yunusi

Zainuddin Labay lahir pada tahun 1890 M, dari pasangan Syaikh Muhammad Yunus al-Khalidiyah dan Rafi'ah. Zainuddin Labay adalah anak tertua. Sejak kecil ia dididik langsung oleh kedua orang tuanya dengan penanaman sistem nilai, pendidikan agama dan pengalaman-pengalaman kehidupan. Zainudin Labay juga pernah mengenyam pendidikan di Hollands Inlandsche School (HIS) dengan sistem pendidikan yang menekankan ilmu-ilmu umum seperti membaca dan menulis, pendidikan dasar, berhitung, atau pencatatan. Namun hanya bertahan hingga kelas empat. ${ }^{24}$

Setelah gagal menyelesaikan studi di HIS, Zainuddin belajar kepada seorang ulama modern di Padang yaitu Syaikh Abdullah Ahmad. Lalu belajar kepada Syaikh Abbas Abdullah, seorang ulama modern yang sealiran dengan Syaikh Abdul Karim Amrullah dan Abdullah Ahmad. Selama dua tahun Zainuddin belajar di Padang Japang, perkembangan bakat dan kemampuannya semakin sempurna. Ia pun diangkat Syaikh Abbas Abdullah untuk menjadi guru bantu di sana. Tahun 1914, Zainuddin pulang ke kampung halaman dan belajar kepada Dr Abdul Karim Amrullah di Surau Jembatan Besi. Karena kemampuan intelektual yang dimiliki Zainuddin Labay cukup baik, ia diberikan kepercayaan untuk menjadi guru bantu di surau tersebut. ${ }^{25}$

Semangat Zainuddin melakukan pembaharuan di lembaga pendidikan pun semakin berkobar-kobar. Ia ikut membangun sistem pendidikan modern melalui

\footnotetext{
${ }^{23}$ Abuddin Nata, Tokoh-Tokoh Pembaharuan Pendidikan Islam di Indonesia, 14.

${ }^{24}$ Burhanuddin Daya, Gerakan Pembahruan Pemikiran Islam kasus Sumatra Thawalib, 84.

${ }^{25}$ Zainuddin Labai el-Yunusi Inisiator Pendidikan Modern, dalam Panglima- ali.com (1April 2013).
} 
Diniyah School. Langkah yang terlihat asing saat itu banyak mengundang sikap anti pati masyarakat. Zainuddin dianggap sebagai ulama perusak agama, dan telah keluar dari Islam. Masyarakat masih menganggap bahwa meniru pola hidup orang Belanda sama dengan kafir.

Namun dengan hati yang tulus Zainuddin menerimanya. Langkah tersebut hanya semata-mata ingin membuktikan bahwa golongan agama dan ulama adalah manusia yang bisa menerima kemajuan. Menurutnya, pengaruh dan hasutan kolonial Belanda lah yang membuat kondisi sosial mereka seperti itu. Selama ini Belanda tidak hanya merusak sendi-sendi kehidupan sosial ekonomi masyarakat, tetapi juga membatasi wawasan dan cara berfikir mereka terhadap kemajuan. Akibatnya masyarakat, terutama golongan agama dan para ulama terkebelakang dalam bidang pendidikan serta kolot cara berfikirnya.

d. Rahmah el-Yunusiah

Rahmah el-Yunusiah adalah tokoh pendidikan Islam wanita pertama yang menaruh perhatian akan pentingnya pendidikan bagi kaum wanita, dialah yang menyadarkan akan peran dan tanggung jawab kaum wanita dalam kancah kehidupan global. Rahmah lahir di Padang Panjang pada tanggal 29 Desember 1900, dan wafat di daerah yang sama pada tanggal 26 Februari 1969. Rahmah merupakan pendiri Madrasah Diniyah Putri Padang Panjang, yang merupakan perguruan wanita Islam pertama di Indonesia, ia juga pelopor berdirinya Tentara Keamanan Rakyat (TKR) di Sumatera Barat . ${ }^{26}$

Rahmah merupakan anak bungsu dari empat bersaudara. Awal mula ia belajar kepada ayahnya, namun hanya berlangsung sebentar, karena ayahnya meninggal dunia ketika ia masih muda. Kemudian ia langsung dibimbing oleh kakak lakilakinya yaitu Zainuddin Labay el-Yunusi dan M. Rasyad. Rahmah sempat mengecam pendidikan di Diniyah School yang didirikan oleh kakak laki-lakinya sendiri yaitu Zainuddin labay. Namun ia merasa banyak persoalan yang tidak dapat dipecahkan oleh sekolah tersebut, termasuk persoalan wanita. Lalu ia belajar kepada ulama terkenal Minangkabau, seperti Haji Abdul karim Amrullah (ayah Buya Hamka), Tuanku Mudo Abdul Hamid Hakim (Pemimpin sekolah

\footnotetext{
${ }^{26}$ Abuddin Nata, Tokoh-Tokoh Pembaharuan Pendidikan Islam di Indonesia, 29.
} 
Thawalib Padang panjang), dan masih banyak lagi ulama yang lainnya. Selain itu ia juga mempelajari ilmu kesehatan (khususnya kebidanan) dan keterampilan wanita, seperti memasak, menenun, dan menjahit. Apa yang telah ia pelajari tersebut ia ajarkan kepada murid-muridnya di Diniyah Putri. ${ }^{27}$

\section{Perkembangan Madrasah di Minagkabau}

Ada beberapa madrasah yang berkembang di Minagkabau, namun dalam artikel ini kita akan menfokuskan pembahasan kepada tiga madrasah saja, diantaranya:

a. Adabiyah School

Adanya kebutuhan rakyat Indonesia terhadap pendidikan yang sistimatis, teratur dan bermutu tinggi sebagaimana pendidikan yang diberikan pemerintahan Belanda terhadap orang-orang Belanda, Eropa dan Cina, membawa Abdullah Ahmad untuk membuka sekolah Adabiyah dengan bantuan para pedagang yang mana anak-anak mereka tidak semua dapat masuk sekolah yang didirikan oleh pemerintahan Belanda. ${ }^{28}$

Adabiyah School ini didirikan pada tahun 1907, ia merupakan sekolah agama pertama di Indonesia di Padang panjang, yang dijadikan rujukan oleh para penulis sejarah pendidikan Islam di Indonesia sebagai madrasah yang tumbuh pada awal pembaharuan. Madrasah ini memiliki sistem pendidikan yang berbeda dengan cara pendidikan di surau. Pembelajaran berjalan dengan berkelas-kelas, belajar mengajar difasilitasi bangku, meja, papan tulis, dan buku-buku. Untuk materi pelajaran pokok terdiri dari pelajaran-pelajaran agama Islam, seperti yang telah berjalan biasanya di surau-surau, ditambah dengan pelajaran umum seperti membaca, menulis, dan berhitung. ${ }^{29}$

Madrasah Adabiyah ini tidak berumur panjang karena faktor situasi di sekitarnya. Sejak awal pendiriannya madrasah itu mendapat tantangan dari masyarakat padang panjang yang kebanyakan tidak menyukai polanya. Namun ada juga data yang menyatakan bahwa faktor lainnya adalah karena kondisi

\footnotetext{
${ }^{27}$ Ibid, 29.

${ }^{28}$ Ibid, 18.

${ }^{29}$ Maksum, Madrasah; Sejarah dan Perkembangannya, 100.
} 
Abdullah Ahmad sebagai seorang pedagang kain dan lokasi madrasah tersebut kurang menguntungkan bagi bisnisnya, dan fasilitas yang tersedia di daerah itu juga kurang cukup dalam memadai penunjang cita-citanya dalam bidang penerbitan surat kabar. ${ }^{30}$

Pada tahun 1909 madrasah ini ditutup lalu pindah ke Padang. Kota ini penduduknya lebih dinamis dari sebelumnya, dan di kota inilah ia mendirikan Adabiyah School yang ke dua, sebuah sekolah umum ditambah pelajaran agama. ${ }^{31}$

Perkembangan Adabiyah School di Padang lebih maju dari sebelumnya, karena selain Abdullah Ahmad sudah lebih berpengalaman, ia juga sudah mengadakan kunjungan ke Singapura untuk meninjau langsung sekolah agama atau madrasah al-Iqbal al-Islamiah yang didirikan oleh Efendi Rafat dari Mesir pada tahun $1908 .^{32}$ Selain itu ia juga banyak mengadakan pembicaraan dengan Syaikh Taher Jalaluddin al-Azhari. Darinya Abdullah Ahmad banyak mendapatkan motivasi dan pengarahan tentang corak pendidikan Islam yang seharusnya dibina menurut ukuran dan acuan yang ada di Mesir. ${ }^{33}$

Adabiyah hidup sebagai madrasah (sekolah Agama) yang pertama di Minangkabau hingga tahun 1914, tetapi kemudian diubah menjadi H.I.S pada tahun 1915. Inilah HIS yang pertama kali memasukkan pelajaran agama dalam rancangan pelajarannya. Dan sekarang Adabiyah telah menjadi sekolah Rakyat dan SMP. ${ }^{34}$

Perkembangan madrasah ini di Padang mencapai kemajuan yang cukup bararti antara lain karena kurikulumnya yang lebih menekannkan pelajaran umum, yang hampir menyerupai HIS (Hollandsch Inlandsche School), karena memang ia banyak mengambil sistemnya dari Belanda. Mata pelajaran agama hanya diberikan dua kali seminggu, selebihnya pelajaran umum dan keterampilan yang

\footnotetext{
${ }^{30}$ Ibid, 101.

${ }^{31}$ Mundzirin Yusuf, Sejarah Peradaban Islam di Indonesia, 152.

${ }^{32}$ Abuddin Nata, Tokoh-Tokoh Pembaharuan Pendidikan Islam di Indonesia, 18.

${ }^{33}$ Burhanuddin Daya, Gerakan Pembaharuan Pemikiran Islam, 83.

${ }^{34}$ Mahmud Yunus, Sejarah Pendidikan islam di Indonesia, 63.
} 
lain. Madrasah ini mendapat pengakuan dari Belanda pada tahun 1915 karena kualitas pendidikan dan kurikulum pengajarnya. ${ }^{35}$

Peristiwa ini menunjukkan bahwa madrasah ini merupakan sekolah pertama setingkat HIS yang didirikan oleh kalangan Islam di Minangkabau, bahkan menjadi yang pertama di Indonesia, dan jika melihat kurikulumnya, Madrasah adabiyah lebih menyerupai sekolah Belanda, hingga ada yang menyebutnya Holandisator bukan modernisator.

Setelah Abdullah Ahmad meninggal dunia pada tahun 1934, gagasan dan pembaharuan pendidikan Islam di Minagkabau tidak terhenti, walau kebanyakan penulis tidak menjelaskan perkembangan dari Madrasah adabiyah, namun ada tokoh-tokoh lain yang juga mengembangkan madrasah tetapi dengan pola yang lain, yang tidak mirip dengan pola Belanda, sehingga lebih mudah diterima masyarakat dan penyebarannya ke desa-desa di wilayah Minangkabau lebih intensif dari madrasah sebelumnya. ${ }^{36}$

b. Madrasah Diniyah

Madrasah Diniyah didirikan 10 Oktober 1915 oleh Zainuddin Labai elYunusi (1890-1924). Sekolah agama yang ditambah dengan pendidikan umum. Sekolah atau Madrasah ini masih bertempat di surau, tetapi diselenggarakan dengan sistem dan metode pendidikan umum, dibentuk perkelas, memiliki papan tulis, buku, dan pelaksaan pembelajaran dilakukan pada sore hari. Madrasah ini dibaginya menjadi dua tingkat, ibtidaiyah dan tsanawiyah. Untuk materi yang pertama kali diajarkan adalah pembacaan al-Qur'an, dan pengetahuan umum terdiri dari sejarah dan ilmu bumi. Secara umum, madrasah ini lebih menekankan pada penguasaan bahasa Arab, sehingga pada kelas yang lebih tinggi teks-teks pengetahuan umum menggunakan bahasa Arab. ${ }^{37}$

Apabila kita mencoba membandingkan antara Madrasah Adabiyah dan Madrasah Diniyah memilki perbedaan yang signifikan. Bentuk pendidikan Madrasah Diniyah lebih sejalan dengan pola yang ditawarkan oleh para pembaharu di Timur Tengah, dan Madrasah Adabiyah sendiri lebih mirip dengan

\footnotetext{
${ }^{35}$ Maksum, Madrasah; Sejarah dan Perkembangannya, 102.

${ }^{36}$ Ibid, 102.

${ }^{37}$ Samsul Nizar, Sejarah Pendidikan Islam; Menelusuri Jejak Sejarah Pendidikan Era Rasulullah Sampai Indonesia, 293.
} 
sekolah Belanda yang ditambah dengan materi pendidikan agama. Maka tidak heran jika Madrasah ini lebih diterima masyarakat luas, hingga dalam waktu lima tahun sudah menyebar ke desa-desa, dan terdata kira-kira ada 15 sekolah di Sumatera Barat yang mengikuti pola Madrasan ini.

c. Madrasah Diniyah Putri

Madrasah Diniyah Putri yang didirikan oleh Rahmah al-Yunusiah, saudara perempuan Zaenuddin Labai. Ini merupakan usaha Rahmah untuk memberikan kesempatan kepada kaum wanita untuk mendapatkan ilmu yang sesuai dengan kodratnya sebagai seorang wanita, hingga kaum wanita dapat berdikari untuk menjadi pendidik yang cakap, aktif dan bertanggung jawab kepada kesejahteraan bangsa dan tanah air.

Dengan bantuan persatuan murid-murid Diniyah School, Rahmah dapat mendirikan Diniyah Putri pada tahun 1November 1923. Ini merupakan suatu prestasi yang baik karena diusianya ke-23 ia sudah memiliki semangat juang yang tinggi. Awal mula terdapat 71 orang murid yang kebanyakan dari ibu-ibu rumah tangga yang masih muda. Pelajaran diberikan selama 3 jam setiap harinya di sebuah pasar usang, Padang Panjang, yang terdiri dari pelajaran agama dan ilmu alat. $^{38}$

Pada tahun 1924 sekolah ini pindah ke sebuah rumah di dekat masjid, dan mulailah diadakan kelas-kelas yang dilengkapi dengan bangku, meja dan papan tulis. Bagian atas dari rumah ini dipergunakan sebagai asrama yang dalam tahun 1925 didiami kira-kira 60 orang murid. Diawal lembaga ini hanya menyediakan pendidikan setingkat MTsdengan nama Diniyah Menengah Pertama, dan setelah berjalan 15 tahun ia membuka program pendidikan lanjutan setingkat Aliyah dengan nama Kulliyat al-Mu'allimat al-Islamiyah (KMI) yang diselenggarakan dengan system asrama. ${ }^{39}$

Namun madrasah ini terkena musibah gempa bumi pada tahun 1926, untuk mengatasi masalah tersebut, maka dibangun sebuah bangunan darurat yang terbuat dari bambu. Selanjutnya pada tahun 1927 Rahmah pergi ke Sumatra Utara

\footnotetext{
${ }^{38}$ Abuddin Nata, Tokoh-Tokoh Pembaharuan Pendidikan Islam di Indonesia, 30.

${ }^{39}$ Jajat Burhanuddin, dkk, Mencetak Muslim Modern, 27.
} 
untuk mengumpulkan dana guna membangun gedung permanen yang dapat diselesaikan pada tahun berikutnya. ${ }^{40}$

Pengaruh politik perjuangan kemerdekaan yang sedang gencar-gencarnya mengenai Madrasah Diniyah ini yang dibawa oleh gurunya yaitu Rasuna Said, namun Rahmah sebagai seorang kepala sekolah dan pendirinya. Karena ia berpendapat pelajaran agama lebih penting dari pelajaran apa pun, masalah politik dengan sendirinya akan diketahui oleh para pelajar pada saat mereka terlibat di dalamnya. Namun karena Rasuna Said sangat popular dalam kiprah politiknya membuat beberapa murid yang tertarik dengan kegiatan politik yang berakibat pada menurutnya aktivitas keagamaan. ${ }^{41}$

Masalah lain yang ia hadapi adalah usaha Permi yang ingin meletakkan semua sekolah golongan pembaharu di Minagkabau berada di bawah naungan organisasi ini. Rahmah juga menolak karena menurutnya keputusan tersebut dapat menghambat perkembangan Diniyah Putri itu sndiri. Keteguhan Rahmah juga terlihat saat ia menolak tawaran Belanda yang akan memberikan subsidi penuh dengan syarat Diniyah Putri menjadi lembaga yang berada di bawah pengawasan Belanda. $^{42}$

Dibawah kepemimpinan Rahmah, Diniyah Putri berkembang pesat. Keberhasilan lembaga ini mendapat perhatian dan pujian dari berbagai tokoh pendidikan, pemimpin nasional, politikus, dan tokoh agama, baik dari dalam maupun luar negri. Maka dari itu pada tahun 1957 Rahmah mendapat gelar Syaikhah dari Senat Guru Besar Universitas al-Azhar, Mesir. Gelar ini belum pernah dianugrahkan kepada siapapun sebelumnya.

\section{d. Sumatera Thuwailib}

Di samping madrasah Diniyah, ada juga surau-surau yang mau ketinggalan, sehingga beransur-ansur surau-surau itu mengubah sistemnya dengan kelas-kelas, bangku meja, seperti madrasah Diniyah yang ada saat itu. Surau yang mengadakan kelas itu adalah Sumatra Thuwalib Padang Panjang yang dipimpin

\footnotetext{
${ }^{40}$ Abuddin Nata, Tokoh-Tokoh Pembaharuan Pendidikan Islam di Indonesia, 31.

${ }^{41}$ Ibid, 32.

${ }^{42}$ Jajat Burhanuddin, dkk, Mencetak Muslim Modern, 28.
} 
oleh Syeikh Abdul Karim Amrullah yang dikenal denga Haji Rasul, yaitu pada tahun 1921 sedangkan surau sendiri berdiri tahun $1914 .^{43}$

Tidak lama kemudian didikuti oleh Sumatra Thuwalib Parabek (Bukit Tinggi) yang dipimpin oleh Syeikh Ibrahim Musa pada tahun 1921 juga, yang mana suraunya sendiri pada tahun 1908. Lalu Sumatra Thuwalib Padang Japang yang berdiri 1906, dan Sumatra Thuwalib Maninjau. Adapun surau Sungayang telah diubah kembali menjadi madrasah School oleh Mahmud Yunus pada tahun 1918, sesudah itu ditutup tahun 1913. Umumnya Sumatra Thuwalib mempunyai 7 kelas (dari kelas 1 sampai kelas 7), seperti madrasah Diniyah pada umumnya. Namun madrasah Diniyah memakai kitab-kitab baru yang dikarang oleh ulama Mesir untuk madrasah-madrasah Mesir, sedangkan kelas yang rendah memakai kitab karangan Zzinuddin Labai al-Yunusi dan guru-guru agama yang lain. Sedangkan Sumatra Thuwalib tetap menggunakan kitab yang lama. ${ }^{44}$

\section{PENUTUP}

Sumatera Barat memang memiliki kedudukan yang sangat penting dalam perkembangan dakwah pendidikan Islam di Indonesia, karena ia merupakan wilayah pertama yang mengalami proses modernisasi dakwah pendidikan Islam pada awal abad ke-20-an. Adanya pembaharuan yang terjadi di Minangkabau sendiri memiliki banyak faktor, baik internal maupun eksternal. Namun diantara faktor yang paling mendominasi adalah banyaknya generasi Minangkabau yang menuntut ilmu ke Timur Tengah, yang membahawa semangat dan ide-ide pembaharuan, yang ditambah lagi kondisi masyarakat yang berada dibawah kekuasaan pemerintahan Belanda, yang selalu menjajah rakyat Indonesia umunya, baik secara materi maupun pendidikan. Hal ini membuat mereka berfikir keras, dan jalan yang paling tepat untuk membangun semanagat dan pola pikir rakyat yaitu melalui pendidikan.

Minangkabau memiliki banyak tokoh pembaharu dalam dunia dakwah pendidikan Islam. Namun diantara tokoh-tokoh yang memberikan pengaruh besar

\footnotetext{
${ }^{43}$ Mahmud Yunus, Sejarah Pendidikan Islam di Indonesia, 73.

${ }^{44}$ Ibid, 73.
} 
dengan adanya lembaga atau sekolah sebagai sarana dakwah yang ia dirikan adalah Abdullah Ahmad yang telah mendirikan Adabiyah School, yang telah memadukan ilmu umum dan ilmu agama, hingga ia mendapat julukan "Holandisator", karena sekolah yang didirikannya menyerupai sekolah-sekolah yang dibangun orang Belanda. Selain itu Zainuddin Labay yang telah berhasil mendirikah Madrasah Diniyah, yang juga memadukan ilmu agama dan ilmu umum, yang mendapat respon baik dari masyarakat karena ilmu agama lebih dominan dari ilmu umum. Sedangkan Rahmah el-Yunusiah telah mendirikan Madrasah Diniyah Putri. Rahmah adalah tokoh pendidikan Islam wanita pertama yang menaruh perhatian akan pentingnya pendidikan bagi kaum wanita, hingga ia mendapat gelar Syaikhah dari Senat Guru Besar Universitas al-Azhar.

Surau sebagai sarana dakwah dalam bidang pendidikan Islam di Suumatra Barat yang mengalami pembaharuan sintem dengan berkelas, adalah Sumatra Thuwalib, namun walau sistemnya berubah, namun mereka tetap menggunakan buku-buku lama, tidak seperti halnya Madrasah Diniyah yang telah memakai kitab-kitab baru yang dikarang oleh ulama Mesir, dan ulama dari madrasah Diniyah itu sendiri.

\section{DAFTAR PUSTAKA}

Asmuni, Yusran, Dirasah Islamiyah III, Pengentar Studi Pemikiran dan Gerakan Pembaharuan dalam Dunia Isam, Jakarta: PT RajaGrafindo Persada, 1998.

Burhanuddin, Jajat, dkk, Mencetak Muslim Modern, Jakarta: Rajawali Press, 2006.

Daya, Burhanuddin, Gerakan Pembahruan Pemikiran Islam kasus Sumatra Thawalib, Yogyakarta: PT Tiara Wacana Yogya, 1995.

Maksum, Madrasah; Sejarah dan Perkembangannya, Jakarta: PT Logos Wacana Ilmu, 1999.

Nata, Abuddin, Pemikiran Para Tokoh Pendidikan Islam; Seri Kajian Filsafat Pendidikan Islam, Jakarta: RajaGrafindo Persada, 2000.

Nata, Abuddin, Tokoh-Tokoh Pembaharuan Pendidikan Islam di Indonesia,Jakarta: PT RajaGrafindo Persada, 2004.

Nizar, Samsul, Sejarah Pendidikan Islam; Menelusuri Jejak Sejarah Pendidikan Era Rasulullah Sampai Indonesia, Jakarta: Kencana, 2007.

Sani, Abdul, Lintasan Sejarah Pemikiran Perkembangan Modern Dalam Islam, Jakarta: PT RajaGrafindo Persada, 1998.

Sholihin, M. Melacak Pemikiran Tasawuf di Nusantara, Jakarta: PT RajaGrafindo Persada, 2005. 
Sunanto, Musyrifah, Sejarah Peradaban Islam Indonesia, Jakarta: PT RajaGrafindo Persada, 2012.

Yunus, Mahmud, Sejarah Pendidikan Islam di Indonesia, Jakarta, Hidakarya Agung, 1996.

Yusuf, Mundzirin, dkk, Sejarah Peradaban islam di Indonesia, Yogyakarta, Penerbit Pustaka, 2006. 